\title{
A NEW PROPOSED STRATEGY FOR CONFLICT RESOLUTION: A LOCAL WISDOM EXPLORATION
}

\author{
Zuraidah ADLINA \\ Universitas Islam Sumatera Utara, Indonesia \\ SYAHLAN \\ Universitas Islam Sumatera Utara, Indonesia
}

(C) The Author(s) 2019

\begin{abstract}
Indonesia has more than two hundred ethnic groups which are productive of local wisdom. This research paper discusses the potential values of local wisdom practices for the religion and social conflict resolutions in Indonesia. An Exploration Analysis was conducted to seek the potential local genious values which then developed as a new strategy to avoid social conflicts due to religuious, political, and inter -group differences. Data obtined revealed that Ethnic Mandailing conflict resolutions in the Framework of Holong Do Mangalap Holong (Love Creates Peace and Harmony) could be potentially made as new strategy to avoid social conflicts. The traditional values of ethnic groups in Indonesia help the local and central government of Indonesia to control the social conflicts. It concluded that Ethnic Mandailing of South Tapanuli of Indonesia has a conflict resolution. Refers to the ethnic values it would be the best example to prevent and help the harmony of community.

(O2019.All rights reserved
\end{abstract}

\section{ARTICLE HISTORY}

Received: 29/03/2019

Accepted: 13/07/2019

Published online: 03/10/2019

\section{KEYWORDS}

Strategy; local genius; Ethnic

Mandailing; social conflicts, resolutions 


\section{Introduction}

Since the reform era in Indonesia in 1998, the frequency of social conflicts due to the growing religious, economic and ethnic and racial sentiments is increasing. Television and social media continue to broadcast social disputes in some regions of Indonesia. Safitri (2011) argued that the emergence of conflicts due to development in Indonesia began in the 1990s; people protest to the government or mega-projects which exploite natural resources in the certain locations. It noted the street vendors were displaced due to the construction of luxury malls in gentrification programs. It reported fishermen complain about the trawling of foreign illegal fishing, cases of illegal logging and illegal loggers. Moreover the corruption cases tend to higher and higher. It found that the public complains continuously appear from unfair compensation for displaced houses (Safitri 2011: 29)

Indonesia's diversity is an integral entity in the national spirit of Unity in Diversity (Bhinneka Tunggal Ika) that keeps the multiethnic proliferation; it is not a barrier to becoming a Nation State which put into a stable and robust form. Unity in Diversity in civil society, and diverse but can make people in a national envinronment coexist peacefully with one another (Supardi 2003: 24). It should be noted that the civil society is often portrayed as an actor, and it has a function to cover a heterogeneous collection of organizations and initiatives with different roles; it functions in a changing context (Brandsen et al., 2017). Individual differences are imbued in a society. Cultural differences are social capital for a nation to avoid conflicts. (Islam 2012: 237). Then Wagiran (2012) elaborated that local wisdom could be interpreted a thought about life. Local knowledge might be translated into social norms, character, and identity. Mastery over local wisdom brings people mind in greatness of humanity (Wagiran 2012: 330). Based on the above theoris, this paper sought the potential social capital of local wisdoms 
of Indonesia to build the national model for peace studies to manage the social conflicts. This paper explores local genious of North Sumatra and develops its to create a model for social conflict resolutions.

\section{Studying Local Wisdom}

Ethnic studies revealed that the local genius of Indonesia has potential values for constructing a model of conflict resolutions. The Conflict Resolution Model (Davidson and Wood, 2004) might give solutions to the government. Indonesia is rich of local genious which needs to revisit potential values for building a new strategy to avoid or control social conflicts due to political and religious or interfaith tensions. Ethnic Mandaialing of North Sumatra has practiced the strategy of conflict prevention which put in the Framework of Holong Do Mangalap Holong (Love Creates peace and Harmony). Thus, for Fajarini (2014) local wisdom is a way of life and various life strategies in the form of activities undertaken by local communities in addressing to the multiple problems. Others may conceive local wisdom or local knowledge as local intelligence (2014: 123-124).Besides, Suhartini (2009: 208) argues that local wisdom is related to adaptation with the environment, she posited that the community acquires and develops an understanding in social life. Local knowledge in the form of ideas, customs norms, cultural values, activities, and equipment as a result of abstraction to manage the environment. Often public understanding of the local environment is an official guide in developing life in their neighborhoods. Then, Qodariah and Armiyati (2013: 11) stated that local wisdom in general can be understood as local ideas that are wise, full of wisdom, good value, embedded and followed by members of the community. Understanding local wisdom is substantially captures the various values that apply in a community. 
The principal benefits of understanding local wisdom are to be accurate and become a reference for any ethnic groups in daily behavior (Tatminingsih and Novita, 2016: 204).

\section{Social Conflict Theory}

Many experts in Social Sciences reported the findings and postulate some theories of Social Conflicts. Theories of social conflict have been elaborated the way of constructing an alternative conflict resolution (ACR). The idea of conflict can be associated with that of power and, in the last resort, with that of coercion. It then becomes distinct from the concept of sociability. It signifies that human beings are friendly but are also capable of opposing one another and struggling with one another. From this point of view, conflict is what happens when the interests of individuals or groups are antagonistic, and they are in battle for status or power. In this instance, the participants in the conflict are sensitive to emotions (Wieviorka, 2010). In every society, there are different types of causes and forms of conflict such as personal conflict, racial conflict, class conflict, political conflict, conflict of values and conflict of interests, communal and non-communal disputes, ethnic conflicts, ideological conflict, cultural conflicts, economic conflicts and social conflicts, and others (Wani, 2011).

It is believed that social conflict could be interpreted as a conflict between members of society that are comprehensive in life. In other words, the interaction or social process between two or more persons as well as ethnic groups may meet any conflicts, in which one party seeks to exclude the other by destroying it, or at least making it powerless (Aisyah, 2014: 192). Furthermore, Wall and Callister (in Prieto-Remón, 2015) define conflicts as 
“.... A process in which one party perceives that its interests are being opposed or negatively affected by another party". The battle appears due to the lack of social control; that society has the illegal actions; out of law enforcers so that violators of thee rule will not feel the fear. Some violators use money and power to avoid the punishment (Kurniawan and Shani, 2014: 3).

In the reality of this kind of life, the actual intercultural conflict in Indonesian society should be quickly resolved. However, it is uncontrollable and turns into a "war of discourse" in the media. Inter-interest discourse wars occur because each party feels that their discourse is considered the most correct. To understand the conflicts arising in the tradition of coaching in university, several concepts of intercultural communication can be used to explore the root causes of, among others, by explaining the idea of in- group vs. out-group, prejudice and stereotypes, and cultural variability (Widiastuti, 2012: 148).

Conflict is a consequence of human interaction with various interests that lie behind it. The conflict between nations and internal conflicts involving tribes in a region becomes a scene that often appears in human history. Conflicts triggered by ethnic differences still occur in Indonesia to date. Indonesia as a multicultural country in there are various ethnic groups make it full of cultural diversity but also a potential conflict that can explode at any time (Hidayat, Widana and Macpal, 2017: 2).

The problem of conflict is no less complex than that of integration of societies. We now know that the attempt to reduce all occurring conflicts among social groups to a universal principle says that of classes, is sterile. It leads either to empty generalizations (such as each community must experience conflicts or to empirically unjustifiable oversimplifications (suchas social class struggle history. It seems advisable, first, to sort out and to classify the problems which are conceived under the general heading of social conflict (Dahrendorf in Milioni et al., 2015). 


\section{Unity in Diversity Model}

Indonesia has a universal model of keeping national unity the plurality of Indonesia. It is so called the Unity in Diversity (Bhinneka Tunggal IkaSanskrit phrase). It is the essence of Indonesian national insight; because it is an Indonesia social cohession to avoid conflicts due to the geographically separated by thousand of Islands and its population is heterogeneous. Under such conditions, the formated Bhinneka Tunggal Ika is not a coincidence but a necessity. Sociologically, the difference is indeed potential for any conflicts, although philosophically, synergic unity is productive as a union with different elements (Tjarsono, 2013: 889). Bhinneka Tunggal Ika was created to keep the harmony of Indonesia which has five different religions, more than 700 local languages and 250 ethnic groups. Thus, Bhinneka Tunggal Ika is the essence of Indonesian national insight because Indonesia is geographically archipelago and its population is heterogeneous. The differences are potential for conflicts, although philosophically, synergic, productive unity is a union of different elements (Suhardi and Nugraha 2009: $1)$.

Bhinneka Tunggal Ika Indonesia is based on multi-ethnicity that refers to ethnic groups or societies with their respective cultures. These ethnic groups are united and administratively organized by the Indonesian national system based on Indonesian national ideology which so called Pancasila and the 1945 Constitution (Sari, 2016: 2). The concept of "Bhinneka" acknowledges diversity, additionally, the idea of "Ika (Sanskrit word)", the only one which seeks national unity. Thus, multi-ethnicity is characterized by differences, followed by unity which is characterized by similarity. So it can be concluded that Bhinneka Tunggal Ika means Diverse but still One and is a statement that recognizes the reality of the pluralistic culture of Indonesian; yet it always aspires to the realization of unity. Indonesia with Unity in 
Diversity means Indonesia, in addition to knowing. State acknowledges the diversity also recognizes unity.

Data found that in the Framework of Holong Do Mangalap Holong (Love Creates peace and Harmony) of Etnic Mandalaing of North Sumatra has the values of local genius which potentially give a new strategy of conflict resolution. Thus, the Framework of Holong Do Mangalap Holong (Love Creates peace and Harmony) of Etnic Mandalaing of North Sumatra plays a vital role to anticipate the social conflicts of religion, economics, social gap and public protest in the society. For instance, the adoption of the Framework of Holong Do Mangalap Holong (Love Creates peace and Harmony) of Etnic Mandalaing of North Sumatra could be transformed into national and global tensions. Thus, the local values the Framework of Holong Do Mangalap Holong (Love Creates peace and Harmony) of the Ethnic Mandailing of North Sumatra already practiced in the multi ethnic relationship with Batak Toba, MinangKabau of West Sumatra as well as immigrants. Data revealed that for Ethnic Mandailing to develop the local values of the Framework of Holong Do Mangalap Holong (Love Creates peace and Harmony) into a modern one is supporting the Bhinneka Tunggal Ika (Unity in Diversity); it is the essence of Indonesian national insight for peace and harmony.

\section{Conclusions}

Data interpretation of the values of local genious of Indonesia give two conclusions:

(1).The potential peace values of ethnic groups in Indonesia could be proposed a strategy for conflicts resolution due to the high tension among the society of the infiltiration of foreign or alien values that disrupted the Unity of Indonesia. The Framework of Holong Do Mangalap Holong (Love 
Creates peace and Harmony) of Ethnic Mandailing has a great potent for a new strategy to avoid social conflicts.

(2). Any attempt to reconstruct the ethnic values to keep the harmony and tolerances in Indonesia could be done by revisiting the inside ethnics and social interaction role model of ethnic groups; build modern conflict resolution strategy which adopts the ethnic values to keep unity of Indonesia and strenthen tolerances among Indonesians.

\section{Disclosure statement}

No potential conflict of interest was reported by the authors.

\section{Contact Information}

E-mail: zuraidah.adlina@ fkip.uisu.ac.id 


\section{References and notes:}

Aisyah, S. (2014), Social Conflict in Religious Interrelations, Tablighi Da'wah Journal, 15(2): 192

Bystrova, E. G. \& Gottschalk, P. (2015). Social Conflict Theory and White-collar Criminals: Why Does the Ruling Class Punish their Own?. Pakistan Journal of Criminology 7(1): $1-15$.

Davidson, J., and Wood, C. (2004). A Conflict Resolution Model. Theory into Practice, 43(1). College of Education, the Ohio State University.

Fajarini, U., (2014), The Role of Local Wisdom in Character Education, Socio Didaktika, 1(2): $123-124$

Hidayat, E.R., Widana, K. \& Macpal, E.A. (2017), Policy Analysis on Handling of Ethnic Conflict in the Sorong City of West Papua, Journal of Peace Studies and Conflict Resolution Program, 3(1): 2

Islam, N., (2012), Representation of Ethnicity in the Framework of Unity in Diversity Media (Papuan Ethnic Study in the Frame of Bhinneka Tuggal Ika in TransTV Program "Minus Family"), Journal of Da'wah Tabligh, 13(2): 237

Kurniawan, D. \& Syani, A. (2014), Factors Causes, Impacts and Conflict Resolution Strategies Between Locals in Way Panji Subdistrict, South Lampung District, Journal of Sociology, 15(1): 3-7.

Milioni, DV. Doudaki, P. Tsiligiannis, V. Papa \& K. Vadratsikas. (2015). Conflict as News and News as Conflict: A Multidimensional Content Analysis of TV News in Cyprus. International Journal of Communication, 9(2015): 2391-2411.

Prieto-Remón, Tomás C., Jose Ramón Cobo-Benita, Isabel Ortiz-Marcos, Angel Uruburu. (2015). Conflict Resolution to Project Performance. Social and Behavioral Sciences 194 ( 2015 ): $155-164$.

Qodariyah, L. \& Armiyati, L. (2013), Local Wisdom Values of Indigenous Peoples Kampung Naga As Alternative Source of Learning, SOCIA, 10(1):1- 11

Safitri, N. (2011), Social Problems and Conflict of Indigenous Peoples of Papua With PT Freeport Indonesia, PERSPECTIVE, 4(1): 29

Sari, E.Y, (2016), The Influence of Understanding The Concept of Unity in Diversity Against Social Relations of Different Students of Tribe, Thesis, University of Lampung: 2.

Suhardi, A.M. \& Nugraha, A., (2009), Application of Bhinneka Tunggal Ika Philosophy in Product Design as a Value Interaction Facility in Society, Journal of Graduate Degree of Art and Design, 1:1.

Suhartini, (2009), Study of Local Wisdom of Society in Natural Resources and Environment Management and Application. Yogyakarta State University: 208

Supardi, P., (2003), Bhinneka Tunggal Ika: The Diversity of Nationality or Culture?, Anthropology of Indonesia, 72(24).

Tatminingsih, S. \& Novita, D. (2016). Local Wisdom and Digital Era Learning: Between Expectations and Facts (Perception of Kindergarten Teachers in Yogyakarta Region): 204

Tjarsono, I., (2013), Pancasila Democracy And Unity in Diversity Solution Heterogeneity. Transnational Journal, 4(2): 889.

Wagiran, (2012), Development of Local Wisdom Based Character of Hamemayu Hayuning Bawana (Identification of Cultural Character-Based Values), Journal of Character Education, 2(3): 330.

Wani, H.A. (2011). Understanding Conflict Resolution. International Journal of Humanities and Social Science 1(2); 104-111.

Widiastuti, T. (2012), Framing Analysis An Intercultural Conflict in Media, Journal Communication Spectrum, 1(2): 148

Wieviorka, M. (2010). Social Conflict. Sociopedia.isa, DOI: 10.1177/205684601054 